\title{
肝細胞がんに対するシスプラチン・リピオドール療法における 嘔吐の危険因子および制吐剤の予防効果の解析
}

\author{
長手俊樹 ${ }^{1}$, 池村健治 ${ }^{2}$, 世古口典子 ${ }^{2}$, 榎屋友幸 ${ }^{2}$, 村木優一 ${ }^{2}$ \\ 岩佐元雄 ${ }^{3}$, 岩本卓也 ${ }^{2}$, 定金 豊 $^{1}$, 奥田真弘 ${ }^{* 2}$ \\ 鈴鹿医療科学大学 薬学部 ${ }^{1}$, 三重大学医学部附属病院 薬剂部 ${ }^{2}$ \\ 三重大学大学院医学系研究科 消化器内科学 ${ }^{3}$
}

\section{Analyses of Risk Factors and Preventive Effect of Antiemetics on Vomiting Induced by Therapy with Cisplatin Suspension in Lipiodol for Hepatocellular Carcinoma}

\author{
Toshiki Nagate ${ }^{1}$, Kenji Ikemura ${ }^{2}$, Noriko Sekoguchi ${ }^{2}$ Tomoyuki Enokiya ${ }^{2}$, Yuichi Muraki ${ }^{2}$, \\ Motoh Iwasa ${ }^{3}$, Takuya Iwamoto ${ }^{2}$, Yutaka Sadakane ${ }^{1}$ and Masahiro Okuda*2 \\ Faculty of Pharmaceutical Sciences, Suzuka University of Medical Science ${ }^{1}$ \\ Department of Pharmacy, Mie University Hospital ${ }^{2}$ \\ Department of Gastroenterology and Hepatology, Mie University Graduate School of Medicine ${ }^{3}$ \\ $\left[\begin{array}{l}\text { Received July 16, } 2015 \\ \text { Accepted August 26, } 2015\end{array}\right]$
}

The combination of 5- $\mathrm{HT}_{3}$ antagonist $\left(5-\mathrm{HT}_{3}\right)$ with dexamethasone (DEX) and aprepitant (AP) is recommended for preventing vomiting when undergoing highly emetogenic chemotherapy including cisplatin (CDDP). Little is known about the efficacy of antiemetic therapy and risk factors on vomiting after hepatic arterial chemotherapy with CDDP. We carried out a retrospective cohort study to analyze the risk factors and preventive effect of antiemetics for vomiting in 77 patients who received therapy with CDDP suspension in lipiodol (CDDP - LIP) for hepatocellular carcinoma for the first time at Mie University Hospital between January 2009 and October 2014. Ten (13\%) and 7 (9\%) patients developed vomiting in acute and delayed phases, respectively. In the overall period (acute and delayed phases), the complete response for vomiting (100\%) in patients with 5- $\mathrm{HT}_{3}$, DEX, and AP was significantly higher than that (65\%) in patients

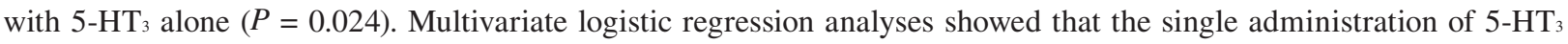
in the acute phase (odds ratio $(\mathrm{OR}): 4.748, P=0.037)$ as well as female gender (OR: $9.439, P=0.047)$ and dose of LIP (OR 1.051, $P=0.029$ ) in the delayed phase were considered to be risk factors of vomiting. These results suggest that a combination antiemetic therapy using $5-\mathrm{HT}_{3}$ with $\mathrm{DEX}$ and AP should be recommended in patients with the above risk factors of vomiting after CDDP - LIP therapy. The present findings provide useful information for the achievement of effective antiemetic therapy to improve the quality of life in patients receiving CDDP $\cdot$ LIP therapy for hepatocellular carcinoma.

Key words — antiemetics, cisplatin, hepatocellular carcinoma, lipiodol, vomiting

\section{緒言}

動注用アイエーコール ${ }^{\circledR}$ (日本化薬（株），東京） は粉末シスプラチン ( cisplatin: CDDP) 製剤であり, リピオドール (lipiodol: LIP) と併用し, 肝動脈化 学療法（transhepatic arterial infusion chemotherapy:
TAI）あるいは肝動脈化学塞栓術（transcatheter arterial chemoembolization: TACE）として肝細胞

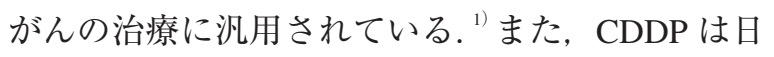
本癌治療学会の「制吐薬適正使用ガイドライン」 で高度催吐リスクに分類され， 5- $\mathrm{HT}_{3}$ 受容体拮抗薬 (5- $\left.\mathrm{HT}_{3}\right)$ ，デキサメタゾン (dexamethasone: DEX),

\footnotetext{
*テ514-8507 三重県津市江戸橋2-174
} 
アプレピタント（aprepitant: AP）の 3 剂併用によ る制吐療法が推奨されている.

肝動脈内投与時の CDDP の血漿中総濃度㧍よ び半減期は, 静脈内投与時とほぼ同じであり, 著 明な差はないと報告されているが（動注用アイ エーコール®50 mg・100 mg, インタビューフォー 厶, 日本化薬株式会社, 2014 年 8 月作成, 改訂 第 8 版)，肝動脈内投与後の CDDP に対する制吐 療法の有効性に関するエビデンスは極めて少な く，適正な制吐療法を推奨するガイドライン等も 存在しない. また, 肝動脈内投与後に塞栓処置を 施すことで, 肝組織内の CDDP の滞留性を高め, 全身への薬物移行性が低下することが報告されて いる. 3) さらに, TACE 施行後の早期には, 塞栓後 症候群と呼ばれる一過性の嘔吐と上腹部痛や発熱 が 60〜100\%の頻度で起こることが知られてい る. ${ }^{4}$ 従って, TACE 施行時には CDDP の体内動態 や催吐作用が静脈内投与時とは異なる可能性があ り，TACEにより CDDPを投与した場合も静脈内 投与時と同様の制吐療法を行うべきか不明である.

我々はこれまでに, 三重大学医学部附属病院に おける CDDP·LIP 療法時の有害事象に関する調 査研究を行い, 悪心・嘔吐の発現率が $50 \%$ であ

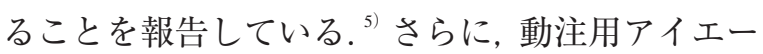
コール®の臨床第 II 相試験において, 制吐剤とし て 5- $\mathrm{HT}_{3}$ 単剤を用いた場合に嘔吐の発現率が $40 \%$ でったことから, ${ }^{6}$ 動注用 CDDP の嘔吐に 対して $5-\mathrm{HT}_{3}$ 単剤での予防効果は不十分である可
能性が高い.また，TACEを施行した肝細胞がんの 患者を対象にした悪心・嘔吐の危険因子に関する 報告は存在するが, ${ }^{7,8)} \mathrm{CDDP} \cdot \mathrm{LIP}$ 療法時の嘔吐につ いての情報はない，以上から，CDDP·LIP 療法によ る嘔吐の危険因子を明らかにし, 患者の QOL (quality of life) 向上に貢献可能な適正な制吐療法 に関するエビデンスを構築することは必須と考えら れる. 本研究では肝細胞がんに対する CDDP·LIP 療法における嘔吐の危険因子並びに制吐剂の予防 効果に関する後ろ向きコホート研究を行った.

\section{方 法}

\section{1. 対象}

2009 年 1 月～ 2014 年 10 月に三重大学医学部附 属病院にて肝細胞がんに対して動注用アイエー コール®（50 mg 以上）が初回投与された患者 106 名を電子カルテより抽出した，抽出した患者のう ち, LIP の投与がない 21 名, 転移性肝がんの 6 名を除外した。さらにほかの抗がん剂を併用して いる 2 名を除外した計 77 名を調查対象とした (図 1). CDDP・LIP 懸濁用液は, 動注用アイエー コール®のバイアルにLIPを懸濁させ調製し, 全 量またはその一部を経カテーテル投与した。最大 CDDP 投与量は $100 \mathrm{mg}$ とし, LIP 使用量は病変部 位や腫瘍サイズの状態に応じて調節した．LIP 投 与量の中央值は $9 \mathrm{~mL}(1 \sim 19 \mathrm{~mL})$ であり, CDDP 投与量の中央值は $100 \mathrm{mg}(50 \sim 100 \mathrm{mg})$ であった.

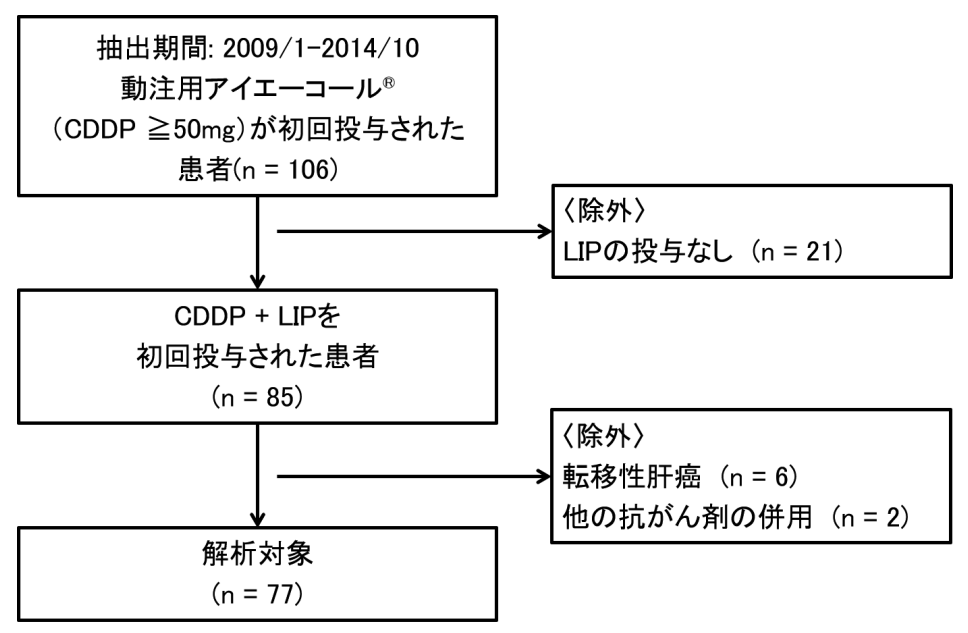

図 1 選択基準のフローチャート CDDP: cisplatin, LIP: lipiodol. 


\section{2. 調査項目および調査方法}

診療記録より対象患者 77 名の初回投与時にお ける術前患者背景として, 性別, 年齢, 身長, 体 重, body mass index (BMI), 肝炎の有無, ChildPugh，血清クレアチニン值（serum creatinine: $\mathrm{SCr}$ ), アスパラギン酸アミノトランスフェラーゼ值 (aspartate aminotransferase: AST)，アラニンアミノ トランスフェラーゼ值（alanine aminotransferase: ALT), 血清総ビリルビン值（total bilirubin: T-Bil）, 病変部位, 術前輸液量の 13 項目, 術後患者背景 として術式, CDDP 投与量, LIP 投与量, 術後輸 液量, 投与された制吐剂, 嘔吐の有無, 嘔吐の発 現時期の 7 項目の計 20 項目について電子カルテ より調査を行った。なお，嘔吐の有無および発現 時期は CDDP 投与後 120 時間までの期間につい て看護記録に基づき調查し，嘔吐の発現時期を急 性期（0２4 時間以内), 遅発期（24〜120 時間） および全期間（0１20 時間）に分類した。また, 嘔吐完全抑制（complete response: CR）率は，制 吐剂の追加投与がなく，嘔吐の発症がないことと した． $5-\mathrm{HT}_{3}$ 受容体拮抗薬として，グラニセトロ ン $3 \mathrm{mg}$ (granisetron: GRAN), パロノセトロン 0.75 mg (palonosetron: PALO)，ラモセトロン $0.3 \mathrm{mg}$ （ramosetron: RAMO）のいずれかを単独投与され た症例を $5-\mathrm{HT}_{3}$ 単独群とした。なお， RAMO お よび PALO は術前に 1 日 1 回投与され, GRAN は術前の 1 日 1 回, あるいは術前並びに術後の 1 日 2 回投与であった. $5-\mathrm{HT}_{3}$ 受容体拮抗薬に加え, 静脈内投与により DEX $6.6 \mathrm{mg}$ を併用した症例を DEX 併用群とした。さらに，APを治療開始前に $125 \mathrm{mg}$ ，翌日と翌々日に各 $80 \mathrm{mg}$ を経口投与し た症例を $\mathrm{DEX}+\mathrm{AP}$ 併用群とした。

\section{3. 統計解析}

CR 率の 2 群間比較には, Fisher's exact test with Bonferroni correction を用いて統計解析を行った。 また，嘔吐の危険因子の解析には，急性期および 遅発期の嘔吐の有無を従属変数とし, 独立変数を 患者背景として単変量ロジスティック回帰分析を 行った。なお，観測度数にゼロを含む場合には， すべての度数に 0.5 を加算して，修正オッズを算 出した. さらに, 単変量ロジスティック回帰分析
にて $P<0.2$ であった独立変数を選択し，ステッ プワイズ増加法による多変量ロジスティック回帰 分析を行った。すべての統計解析は IBM SPSS Statistics Ver 22（日本 IBM(株), 東京）を使用し, 仮説検定の有意水準を $P<0.05$ とした.

\section{4. 倫理規定}

本研究は三重大学医学部附属病院臨床研究倫理 審査委員会の承認（No 1474）を受け実施した。

\section{結 果}

\section{1. 患者背景}

解析対象患者 77 名の患者背景を示した（表 1). 男性 61 名, 女性 16 名であり, 年齢の中央值は 71 歳であった。嘔吐は, 急性期 10 例 $(13 \%)$, 遅発期 7 例（9\%）拈よび全期間 16 例（21\%）

表 1 対象患者背景

\begin{tabular}{|c|c|}
\hline 性別（男性 / 女性） & $61(79 \%) / 16(21 \%)$ \\
\hline 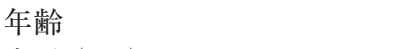 & $71 \quad(48-84)$ \\
\hline 身長（cm） & $160.6(139.7-180.5)$ \\
\hline 体重（kg） & $58.3(37.8-86.0)$ \\
\hline BMI $\left(\mathrm{kg} / \mathrm{m}^{2}\right)$ & $22.4(15.1-28.9)$ \\
\hline $\begin{array}{l}\text { 肝炎 } \\
\text { ( } \mathrm{HBV} / \mathrm{HCV} / \text { nonB nonC) }\end{array}$ & \begin{tabular}{c|c}
8 \\
$(10 \%)$
\end{tabular}$/ \begin{array}{c}49 \\
(64 \%)\end{array} / \begin{array}{c}20 \\
(26 \%)\end{array}$ \\
\hline $\begin{array}{l}\text { Child-Pugh（A/B） } \\
\text { 検查值 }\end{array}$ & $41(53 \%) / 36(47 \%)$ \\
\hline $\mathrm{SCr}(\mathrm{mg} / \mathrm{dL})$ & $0.79 \quad(0.35-4.33)$ \\
\hline $\operatorname{AST}(\mathrm{U} / \mathrm{L})$ & $52(20-311)$ \\
\hline $\operatorname{ALT}(\mathrm{U} / \mathrm{L})$ & $35(6-238)$ \\
\hline T-Bil（mg/dL) & $0.6 \quad(0.3-1.8)$ \\
\hline $\begin{array}{l}\text { 病変部位 } \\
\text { (両葉 / 右葉 / 左葉) } \\
\text { 化学療法 }\end{array}$ & \begin{tabular}{c|c}
52 \\
$(68 \%)$
\end{tabular}$/\left(\begin{array}{c}12 \\
(16 \%)\end{array} /\left(\begin{array}{c}13 \\
(17 \%)\end{array}\right.\right.$ \\
\hline LIP 投与量 (mL) & $9(1-19)$ \\
\hline $\mathrm{CDDP}$ 投与量 $(\mathrm{mg})$ & $100(50-100)$ \\
\hline 術前輸液量（mL） & $1500 \quad(0-2500)$ \\
\hline 術後輸液量 $(\mathrm{mL})$ & $3000 \quad(1000-5500)$ \\
\hline $\begin{array}{l}\text { 術式 } \\
\text { ( TACE / TAI / TACE·TAI併用) } \\
\text { 制吐剂 }\end{array}$ & \begin{tabular}{c|c}
24 & 32 \\
$(31 \%)$ & $\mid \begin{array}{c}21 \\
(42 \%)\end{array} /(27 \%)$
\end{tabular} \\
\hline $5-\mathrm{HT}_{3}$ 単独 & $20(26 \%)$ \\
\hline $5-\mathrm{HT}_{3}+\mathrm{DEX}$ & $37(48 \%)$ \\
\hline $5-\mathrm{HT}_{3}+\mathrm{DEX}+\mathrm{AP}$ & $17(22 \%)$ \\
\hline $\begin{array}{l}5-\mathrm{HT}_{3}+\mathrm{AP} \\
\text { 制吐剂なし }\end{array}$ & $\begin{array}{ll}2 & (3 \%) \\
1 & (1 \%)\end{array}$ \\
\hline $\begin{array}{l}\text { 嘔吐 } \\
\text { (急性期 / 遅発期 / 全期間 })\end{array}$ & \begin{tabular}{c|c}
10 & 7 \\
$(13 \%)$ & $(9 \%)$
\end{tabular} \\
\hline
\end{tabular}

数值は中央值 (最小值 - 最大值) および人数（\%) で表記. AP: aprepitant, CDDP: cisplatin, DEX: dexamethasone, LIP: lipiodol, TACE: transcatheter arterial chemoembolization, TAI: transhepatic arterial infusion. 
で認められた。また, $5-\mathrm{HT}_{3}$ 単独は 20 名 $(26 \%)$ ， DEX 併用は 37 名 $(48 \%)$ および DEX + AP 併用 は 17 名（22\%）であった。

\section{2. 嘔吐完全抑制率}

各投与群における急性期，遅発期および全期間 の CR 率を図 2-A に示した。急性期の CR 率は,

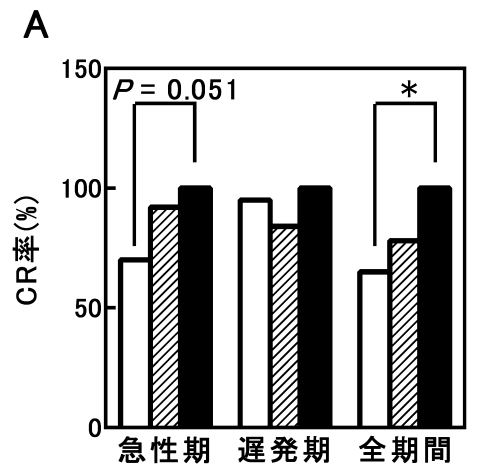

B

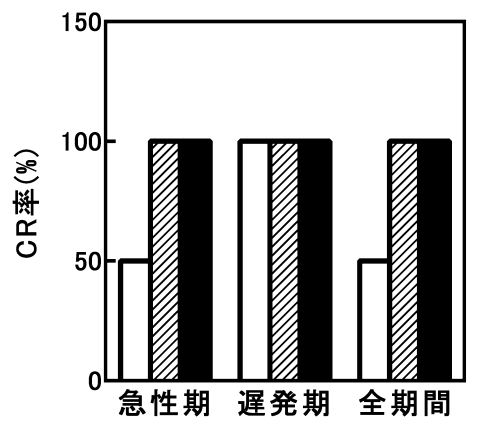

C

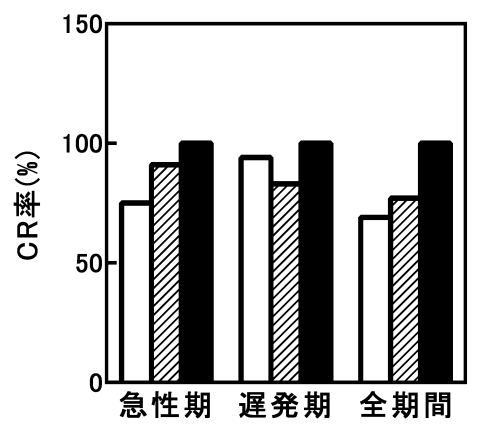

図 2 急性期，遅発期および全期間における嘔吐完全 抑制（CR: complete response）率

(A) 各制吐剤投与群における $\mathrm{CR}$ 率, $\square 5-\mathrm{HT}_{3}(\mathrm{n}=20)$, $\mathbb{Z} 5-\mathrm{HT}_{3}+\mathrm{DEX}(\mathrm{n}=37), \square 5-\mathrm{HT}_{3}+\mathrm{DEX}+\mathrm{AP}(\mathrm{n}=17)$, (B) PALO 投与例に扩ける CR 率, $\square$ PALO $(\mathrm{n}=4), \mathbb{Z}$ PALO $+\operatorname{DEX}(\mathrm{n}=2), \boldsymbol{D A L O}+\mathrm{DEX}+\mathrm{AP}(\mathrm{n}=11), \quad(\mathrm{C})$ GRAN . RAMO 投与例に㧈ける CR 率. $\square$ GRAN or RAMO $(\mathrm{n}=16)$, ש GRAN or RAMO + DEX $(\mathrm{n}=35), \quad \square$ GRAN or RAMO + DEX $+\mathrm{AP}(\mathrm{n}=6)$. AP: aprepitant, DEX: dexamethasone, GRAN granisetron, PALO: palonosetron, RAMO: ramosetron. $* P<0.05$, Fisher's exact test with Bonferroni correction.
5-HT 3 単独群（70\%）および DEX 併用群（91\%） であったが，DEX + AP 併用群では $100 \%$ であっ た（図 2-A)。遅発期の CR 率は, 5- $\mathrm{HT}_{3}$ 単独群 （95\%）およびDEX 併用群（84\%）であったが, DEX + AP 併用群では $100 \%$ であった。また，全 期間の CR 率は, 5- $\mathrm{HT}_{3}$ 単独群（65\%）と比較し, $\mathrm{DEX}+\mathrm{AP}$ 併用群 $(100 \%$ ）で有意な差が認めら れた（ $P=0.024 ）($ 図 2-A).

さらに，PALO 投与例（図 2-B）および GRAN· RAMO 投与例（図 2-C）に再分類し，各投与例 の CR 率についてサブグループ解析を行った. PALO 投与例では, すべての期間で DEX 併用群 ( $\mathrm{n}$ =2）㧍よび $\mathrm{DEX}+\mathrm{AP}$ 併用群 $(\mathrm{n}=11)$ の $\mathrm{CR}$ 率

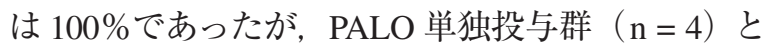
比較し，有意な差は認められなかった（図 2-B）. $\mathrm{GRAN} \cdot \mathrm{RAMO}$ 投与例では, DEX + AP 併用群の CR 率はすべての期間において 100\%であったが, ほかの投与群と比較し有意な差は認められなかっ た（図 2-C）。

\section{3. 単変量ロジスティック回帰分析による急性期 および遅発期における嘔吐の危険因子の解析}

急性期および遅発期における嘔吐の有無を従属 変数とし，単変量ロジスティック回帰分析により 得られたオッズ比（odds ratio: OR），95\%信頼区 間および $P$ 值を示した（表 2，3）。急性期では嘔 吐の有意な危険因子として $5-\mathrm{HT}_{3}$ 単独投与（ OR: 5.679, $P=0.015 ）$ が挙げられ, 遅発期では有意 な独立変数は認められなかった.

\section{4. 多変量ロジスティック回帰分析による急性期 および遅発期における嘔吐の危険因子の解析}

単変量ロジスティック回帰分析において $P<0.2$ であった独立変数は, 急性期では $\operatorname{SCr}(P=0.196)$, AST $(P=0.097)$, 術前輸液量 $(P=0.138)$, 術後 輸液量 $(P=0.082)$ TACE $(P=0.178), 5-\mathrm{HT}_{3}$ 単 独 $(P=0.015), 5-\mathrm{HT}_{3}+\mathrm{DEX}+\mathrm{AP}(P=0.178)$ の 7 変数であった。遅発期では, 性別（女性）（P $=0.148)$, 身長 $(P=0.186)$, 体重 $(P=0.123)$, AST $(P=0.067), \quad$ LIP 投与量 $(P=0.103)$, 術後 輸液量 $(P=0.145), 5-\mathrm{HT}_{3}+\mathrm{DEX}(P=0.068)$ の 7 変数であった。 これらの独立変数を用い, 多変 
表 2 急性期における嘔吐の危険因子に関する単変量ロジスティック回帰分析

\begin{tabular}{|c|c|c|c|}
\hline & オッズ比 & 95\%信頼区間 & $P$ 值 \\
\hline 性別（女性） & 0.946 & $0.180-4.966$ & 0.948 \\
\hline 年齢 & 1.009 & $0.926-1.100$ & 0.838 \\
\hline 身長（cm） & 1.014 & $0.935-1.099$ & 0.737 \\
\hline 体重（kg） & 1.007 & $0.944-1.075$ & 0.826 \\
\hline BMI $\left(\mathrm{kg} / \mathrm{m}^{2}\right)$ & 0.989 & $0.785-1.246$ & 0.925 \\
\hline Child-Pugh & 1.850 & $0.478-7.163$ & 0.373 \\
\hline \multicolumn{4}{|l|}{ 検査值 } \\
\hline $\mathrm{SCr}(\mathrm{mg} / \mathrm{dL})$ & 1.029 & $0.985-1.075$ & 0.196 \\
\hline $\operatorname{AST}(\mathrm{U} / \mathrm{L})$ & 0.969 & $0.935-1.006$ & 0.097 \\
\hline $\operatorname{ALT}(\mathrm{U} / \mathrm{L})$ & 0.983 & $0.949-1.018$ & 0.341 \\
\hline T-Bil（mg/dL) & 0.917 & $0.737-1.142$ & 0.440 \\
\hline \multicolumn{4}{|l|}{ 病変部位 } \\
\hline 両葉 & 0.685 & $0.175-2.685$ & 0.587 \\
\hline 右葉 & 0.566 & $0.065-4.928$ & 0.606 \\
\hline 左葉 & 2.443 & $0.540-11.061$ & 0.246 \\
\hline \multicolumn{4}{|l|}{ 化学療法 ～～～～～} \\
\hline LIP 投与量 $(\mathrm{mL})$ & 0.986 & $0.963-1.010$ & 0.241 \\
\hline CDDP 投与量 $(\mathrm{mg})$ & 1.000 & $0.949-1.054$ & 0.999 \\
\hline 術前輸液量（mL） & 0.922 & $0.828-1.026$ & 0.138 \\
\hline 術後輸液量 $(\mathrm{mL})$ & 0.931 & $0.859-1.009$ & 0.082 \\
\hline \multicolumn{4}{|l|}{ 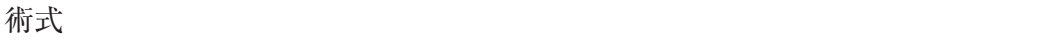 } \\
\hline TACE & 2.526 & $0.656-9.732$ & 0.178 \\
\hline TAI & 0.562 & $0.134-2.361$ & 0.431 \\
\hline TACE·TAI 併用 & 0.632 & $0.123-3.249$ & 0.582 \\
\hline \multicolumn{4}{|l|}{ 制吐剂 } \\
\hline $5-\mathrm{HT}_{3}$ 単独 & 5.679 & $1.407-22.925$ & $0.015^{*}$ \\
\hline $5-\mathrm{HT}_{3}+\mathrm{DEX}$ & 0.416 & $0.099-1.747$ & 0.231 \\
\hline $5-\mathrm{HT}_{3}+\mathrm{DEX}+\mathrm{AP}$ & $0.137^{\text {a) }}$ & $0.008-2.469$ & 0.178 \\
\hline
\end{tabular}

量ロジスティック回帰分析を行った(表 4). なお, $5-\mathrm{HT}_{3}+\mathrm{DEX}+\mathrm{AP}$ は度数にゼロが含まれるため (表 2)，多変量ロジスティック回帰分析には適応 できず独立変数から除外した。また，独立変数に おける多重共線性を検討したが，相関行列表より 相関係数が 0.7 以上の強い相関を示す因子は含ま れていなかった。

多変量ロジスティック回帰分析の結果より独立 した有意な危険因子として，急性期では 5-HT3 単 独（OR: 4.748， $P=0.037 ）$ であった。また，遅 発期では女性（OR: 9.439， $P=0.047 ）$, LIP 投与 量（OR: 1.051, $P=0.029 ）$ であった（表 4).

\section{考察}

CDDP を用いた肝動脈化学療法による嘔吐の危 険因子や制吐療法の有効性に関する情報は極めて 少ない。本研究では CDDP·LIP 療法における嘔
吐の危険因子を検討し, $5-\mathrm{HT}_{3}+\mathrm{DEX}+\mathrm{AP}$ の 3 剂併用による制吐療法がより予防効果が高いこと を示唆した初めての報告である.

本研究において, CDDP 投与 120 時間後まで (全 期間）の $5-\mathrm{HT}_{3}$ 単独投与時における嘔吐の発現率 は $35 \%$ であり（図 2-A）, 過去の報告 ${ }^{6}$ とほぼ一 致した結果であった. 多変量ロジスティック回帰 分析の結果より, 急性期の嘔吐に対する $5-\mathrm{HT}_{3}$ 単 独投与の OR は $4.748(P=0.037 ）$ であり（表 4), $5-\mathrm{HT}_{3}$ 単独投与では嘔吐の予防効果は不十分であ り，DEX 並びにAPの併用投与が必要である可 能性が示唆された。

DEX 併用群では，5-HT3 単独群と比較し，CR 率に 2 群間で有意な差は認められず，全期間での 嘔吐発現率が $22 \%$ であったことから（図 2-A）, DEXの上乗せ効果は認められるが, 嘔吐の予防 効果は依然として不十分であると考えられる。一 方で, $\mathrm{DEX}+\mathrm{AP}$ 併用時には急性期および遅発期 
表 3 遅発期における嘔吐の危険因子に関する単変量ロジスティック回帰分析

\begin{tabular}{|c|c|c|c|}
\hline & オッズ比 & 95\%信頼区間 & $P$ 值 \\
\hline 性別（女性） & 3.288 & $0.655-16.511$ & 0.148 \\
\hline 年齢 ～～～～～～～～ & 1.042 & $0.937-1.159$ & 0.447 \\
\hline 身長（cm） & 0.935 & $0.845-1.033$ & 0.186 \\
\hline 体重（kg） & 0.933 & $0.854-1.019$ & 0.123 \\
\hline BMI $\left(\mathrm{kg} / \mathrm{m}^{2}\right)$ & 0.932 & $0.696-1.248$ & 0.636 \\
\hline Child-Pugh & 0.424 & $0.077-2.331$ & 0.323 \\
\hline \multicolumn{4}{|l|}{ 検査值 ～～～～～～～} \\
\hline $\mathrm{SCr}(\mathrm{mg} / \mathrm{dL})$ & 0.998 & $0.977-1.020$ & 0.878 \\
\hline AST（U/L） & 1.016 & $0.999-1.033$ & 0.067 \\
\hline ALT (U/L) & 1.003 & $0.981-1.025$ & 0.778 \\
\hline T-Bil（mg/dL） & 0.973 & $0.776-1.220$ & 0.812 \\
\hline \multicolumn{4}{|l|}{ 病変部位 } \\
\hline 両葉 & 1.223 & $0.220-6.791$ & 0.818 \\
\hline 右葉 & 2.400 & $0.408-14.107$ & 0.333 \\
\hline 左葉 & $0.284^{\text {a) }}$ & $0.015-5.283$ & 0.399 \\
\hline \multicolumn{4}{|l|}{ 化学療法 ～～～～～} \\
\hline LIP 投与量 $(\mathrm{mL})$ & 1.023 & $0.995-1.051$ & 0.103 \\
\hline CDDP 投与量 $(m g)$ & 5.680 & $0.309-104.234$ & 0.242 \\
\hline 術前輸液量（mL） & 0.942 & $0.833-1.065$ & 0.342 \\
\hline 術後輸液量（mL） & 1.070 & $0.977-1.172$ & 0.145 \\
\hline \multicolumn{4}{|l|}{ 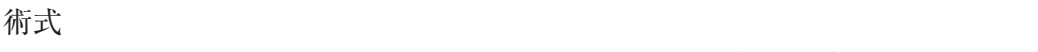 } \\
\hline TACE & 0.873 & $0.157-4.853$ & 0.876 \\
\hline TAI & 0.533 & $0.097-2.939$ & 0.470 \\
\hline TACE·TAI 併用 & 2.167 & $0.442-10.625$ & 0.341 \\
\hline \multicolumn{4}{|l|}{ 制吐剤 } \\
\hline 5-HT3 単独 & 0.447 & $0.050-3.964$ & 0.470 \\
\hline $5-\mathrm{HT}_{3}+\mathrm{DEX}$ & 7.548 & $0.863-66.038$ & 0.068 \\
\hline $5-\mathrm{HT}_{3}+\mathrm{DEX}+\mathrm{AP}$ & $0.204^{a)}$ & $0.011-3.753$ & 0.285 \\
\hline
\end{tabular}

a) 修正オッズ比. AP: aprepitant, CDDP: cisplatin, DEX: dexamethasone, LIP: lipiodol, TACE: transcatheter arterial chemoembolization, TAI: transhepatic arterial infusion.

表 4 嘔吐の危険因子に関する多変量ロジスティック回帰分析

\begin{tabular}{|c|c|c|c|c|}
\hline & & "オッズ比 & "95\%信頼区間 & $P$ 值 \\
\hline 急性期 & $5-\mathrm{HT}_{3}$ 単独 & 4.748 & $1.096-20.564$ & 0.037 * \\
\hline \multirow{2}{*}{ 遅発期 } & 性別（女性） & 9.439 & $1.027-86.727$ & $0.047^{*}$ \\
\hline & LIP 投与量 & 1.051 & $1.005-1.098$ & 0.029 * \\
\hline
\end{tabular}

$* P<0.05$. LIP: lipiodol.

の嘔吐が完全に抑制されており（図2-A），単変 量ロジスティック回帰分析の結果より，急性期お よび遅発期の嘔吐に対する $5-\mathrm{HT}_{3}+\mathrm{DEX}+\mathrm{AP} の$ OR はそれぞれ $0.137(P=0.178), 0.204(P=0.285)$

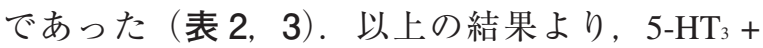
$\mathrm{DEX}+\mathrm{AP}$ の 3 剂併用は, CDDP·LIP 療法の嘔吐 に対してより予防効果の高い制吐療法であること が示唆された。 また，嘔吐の危険因子を持たない 患者( LIP 投与量 $9.5 \mathrm{~mL}$ 未満並びに男性, 計 31 名) の制吐剂の予防効果について解析したところ, $5-\mathrm{HT}_{3}$ 単独群（n=10）における全期間の CR 率 $(60 \%)$ と比較し, DEX 併用群 $(\mathrm{n}=16)$ では 88\%（ $P=0.363 ）$ DEX+AP 併用群（ $\mathrm{n}=5 ）$ では
100\%（ $P=0.612 ）$ であり（デー夕未掲載）, 有意 な差はないが, DEX 併用および DEX+AP 併用投 与により高い抑制効果が認められた。 以上から, 嘔吐の危険因子を持たない患者においても，少な くとも DEX を併用する必要があると考えられる.

PALO は, ほかの 5-HT3 受容体拮抗薬と比較し, 半減期が約 40 時間と長い特徵を有している（ア ロキシ®静注 $0.75 \mathrm{mg}$ ・点滴静注バッグ $0.75 \mathrm{mg}$, インタビューフォーム, 大鵬薬品工業株式会社, 2014 年 4 月改訂, 第 6 版). 高度催吐性化学療法 を受けた患者を対象に GRAN およびPALO の有 効性を比較した過去の報告において, PALO が遅 発性嘔吐に有効であることが示されている. ${ }^{9)}$ 本 
研究では, 5-HT3 受容体拮抗薬として GRAN, PALO，RAMOのいずれかが投与されており，図 2-A で示した遅発性嘔吐の抑制効果にPALO の影 響が含まれている可能性がある。そこで, PALO 投与例および GRAN·RAMO 投与例に分類し, サ ブグループ解析を行った（図 2-B, C). その結果, PALO 投与例では併用薬の有無にかかわらず遅発 期における嘔吐は完全に抑制されており（図 2-B）, 過去の報告と同様に遅発性嘔吐に有効性 を示す可能性が示された(図2-B). しかしながら, 本研究において CDDP·LIP 療法の嘔吐に対する PALO の有効性を示すためには，投与例が少なく 更なる検討が必要である。一方で，PALO 投与例 を除いた GRAN·RAMO 投与例では DEX + AP 併 用群における急性期および遅発期の CR 率は $100 \%$ であったことから（図2-C），投与された $5-\mathrm{HT}_{3}$ 受容体拮抗薬の種類に関係なく $\mathrm{DEX}+\mathrm{AP}$ 併用は CDDP·LIP 療法による嘔吐に対して高い 有効性を示すことが示唆された。

また，5-HT3 単独投与群，DEX 併用群および $\mathrm{DEX}+\mathrm{AP}$ 併用群の患者背景を比較したところ, Child-Pugh 並びに術前輸液量に有意な違いが認め られた (Supplementary Data 1). しかしながら， これらの独立変数は多変量ロジスティック回帰分 析の結果より，嘔吐の有意な危険因子に含まれな かったことから，この患者背景の違いは嘔吐発症 に及ぼす影響は低いと考えられる。

次に, CDDP·LIP 療法による嘔吐の危険因子に ついての報告が存在しないことから，嘔吐の危険 因子の探索を行った。多変量ロジスティック回帰 分析の結果から，遅発期における嘔吐の独立した 危険因子として女性（OR: 9.439）抒よび LIP 投 与量（OR: 1.051）が挙げられた。がん化学療法 によって誘発される悪心・嘔吐は，一般的に男性 より女性に発現しやすいことが知られ, ${ }^{10)}$ TACE 後の嘔吐の危険因子として女性が報告されてい る. ${ }^{78)}$ 以上から, 過去の報告と同様に, CDDP. LIP 療法においても女性が嘔吐の危険因子である ことが示唆された。一方で，これまでにLIPが嘔 吐の危険因子であることを示す報告は存在しない が，LIP の副作用には頻度不明ではあるが嘔吐が 報告されているため（リピオドール®480 注 10
$\mathrm{mL}$ ，インタビューフォーム，テルモ株式会社， 2014 年 9 月改訂, 第 6 版), LIP の投与量には十 分注意が必要であると考えられる。

本研究の限界は, 症例数が少なく, 後ろ向き研 究であることが考えられる。ささに, 嘔吐の有無 および発現時期を看護記録に基づき調査したた め，記録漏れ等の可能性を否定できないことであ る. また, 嘔吐発症の危険因子として performance status の低下や, ${ }^{10)}$ TACE を施行した肝細胞がん患 者においてはペンタゾシンの投与が報告されてい るが, 7) 本研究では症例数や収集できた情報に限 りがあり詳細に検討することができなかった。今 後は前向きな検討により患者個々の詳細な情報を 収集したうえで, CDDP·LIP 療法による嘔吐の危 険因子および制吐療法の予防効果に関して更なる 検証が必要と考えられる.

以上より, CDDP·LIP 療法による嘔吐に対して, $5-\mathrm{HT}_{3}$ 単独投与での抑制効果は不十分な場合があ り，嘔吐の危険因子を有する患者には， $5-\mathrm{HT}_{3}+$ $\mathrm{DEX}+\mathrm{AP}$ の 3 剂併用による制吐療法がより確実 な予防方法と考えられた。本研究成果は, CDDP·LIP 療法による嘔吐の危険因子を初めて示 唆し, 肝細胞がん患者の QOL 向上に貢献可能な 有効性の高い制吐療法を推進するための臨床上重 要な新知見である.

\section{利益相反}

開示すべき利益相反はない.

\section{引用文献}

1）“科学的根拠に基づく肝癌診療ガイドライン 2013年版”, 金原出版, 東京, 2013, pp1-220.

2）日本癌治療学会 “制吐薬適正使用ガイドライン 2010", 金原出版, 東京, 2010, pp1-92.

3) Tegeder I, Bräutigam L, Seegel M, Al-Dam A, Turowski B, Geisslinger G, Kovács AF, Cisplatin tumor concentrations after intra-arterial cisplatin infusion or embolization in patients with oral cancer, Clin Pharmacol Ther, 2003, 73, 417-426.

4) Dhand S, Gupta R, Hepatic transcatheter arterial chemoembolization complicated by postemboliza- 
tion syndrome, Semin Intervent Radiol, 2011, 28, 207-211.

5）宮澤憲治, 世古口典子, 岩本卓也, 村木優一, 田中 秀明, 岩佐元雄, 山門亭一郎, 竹田 寛, 竹井 謙之, 奥田真弘, 原発性肝がんに対するシスプラ チン・リピオドール療法時の有害事象調査, 医療 薬学, 2008, 34, 794-799.

6) Yoshikawa M, Ono N, Yodono H, Ichida T, Nakamura $\mathrm{H}$, Phase II study of hepatic arterial infusion of a fine-powder formulation of cisplatin for advanced hepatocellular carcinoma, Hepatol Res, 2008, 38, 474-483.

7）冠木雅子, 東原大樹, 角田真美, 藤田洋子, 増田 純一, 金 京子, 上口貴志, 大須賀慶悟, 富山 憲幸, 肝細胞癌に対する経カテーテル的肝動脈 化学塞栓術における制吐剤の術前投与と急性嘔 吐の発現頻度に関する後方視的調査, 日本化学
療法学会雑誌, 2013, 40, 197-201.

8) Wang SY, Zhu WH, Vargulick S, Lin SB, Meng ZQ, Nausea and vomiting after transcatheter arterial chemoembolization for hepatocellular carcinoma: incidence and risk factor analysis, Asian Pac J Cancer Prev, 2013, 14, 5995-6000.

9) Saito M, Aogi K, Sekine I, Yoshizawa H, Yanagita Y, Sakai H, Inoue K, Kitagawa C, Ogura T, Mitsuhashi $\mathrm{S}$, Palonosetron plus dexamethasone versus granisetron plus dexamethasone for prevention of nausea and vomiting during chemotherapy: a double-blind, double-dummy, randomised, comparative phase III trial, Lancet Oncol, 2009, 10, 115-124.

10) Pollera CF, Giannarelli D, Prognostic factors influencing cisplatin-induced emesis. Definition and validation of a predictive logistic model, Cancer, 1989, 64, 1117-1122.

Supplementary data 1 制吐剤投与群間における患者背景

\begin{tabular}{|c|c|c|c|c|}
\hline & $\begin{array}{c}5-\mathrm{HT}_{3} \text { 単独 } \\
(\mathrm{n}=20)\end{array}$ & $\begin{array}{c}5-\mathrm{HT}_{3}+\mathrm{DEX} \\
\quad(\mathrm{n}=37)\end{array}$ & $\begin{array}{c}5-\mathrm{HT}_{3}+\mathrm{DEX}+\mathrm{AP} \\
(\mathrm{n}=17)\end{array}$ & $P$ 值 ${ }^{a)}$ \\
\hline 性別（男性 / 女性） & $17(85 \%) / 3(15 \%)$ & $28(76 \%) / 9(24 \%)$ & $13(76 \%) / 4(24 \%)$ & 0.700 \\
\hline 年歯令 & $72(59-82)$ & $72(60-84)$ & $69(48-80)$ & 0.278 \\
\hline 身長（cm） & $162.5(139.7-174.3)$ & $160.0(141.5-180.5)$ & $164.0 \quad(140.2-176.0)$ & 0.552 \\
\hline 体重（kg） & $58.8 \quad(41.2-71.6)$ & $58.3(41.3-82.6)$ & $56.4(37.8-86.0)$ & 0.805 \\
\hline BMI $\left(\mathrm{kg} / \mathrm{m}^{2}\right)$ & $22.3(19.7-27.3)$ & $22.8 \quad(16.6-82.6)$ & $21.7(15.1-27.8)$ & 0.315 \\
\hline \multicolumn{5}{|l|}{ 肝炎 } \\
\hline HBV & $1(5 \%)$ & $4(11 \%)$ & $2(12 \%)$ & 0.723 \\
\hline $\mathrm{HCV}$ & $14(70 \%)$ & $24(65 \%)$ & $10 \quad(59 \%)$ & 0.777 \\
\hline nonB nonC & $5(25 \%)$ & $9(24 \%)$ & $5(29 \%)$ & 0.921 \\
\hline \multicolumn{5}{|l|}{ Child-Pugh } \\
\hline A & $15(75 \%)$ & $21 \quad(57 \%)$ & $4(24 \%)$ & $0.007 *$ \\
\hline \multicolumn{5}{|l|}{ 検査值 ～～～～～～} \\
\hline $\mathrm{SCr}(\mathrm{mg} / \mathrm{dL})$ & $0.81 \quad(0.51-4.33)$ & $0.84 \quad(0.45-1.08)$ & $0.76(0.35-1.01)$ & 0.639 \\
\hline $\operatorname{AST}(\mathrm{U} / \mathrm{L})$ & $51 \quad(26-102)$ & $55(26-311)$ & $47 \quad(20-118)$ & 0.386 \\
\hline ALT (U/L) & $33(6-238)$ & $39(12-99)$ & $33(9-62)$ & 0.243 \\
\hline T-Bil $(\mathrm{mg} / \mathrm{dL})$ & $0.7 \quad(0.4-1.7)$ & $0.7 \quad(0.3-1.7)$ & $0.6(0.4-1.8)$ & 0.854 \\
\hline \multicolumn{5}{|l|}{ 病変部位 } \\
\hline 両葉 & $15(75 \%)$ & $26(70 \%)$ & $9(53 \%)$ & 0.319 \\
\hline 右葉 & $1 \quad(5 \%)$ & $6(16 \%)$ & $4(24 \%)$ & 0.273 \\
\hline 左葉 & $4 \quad(20 \%)$ & $5(14 \%)$ & $4 \quad(24 \%)$ & 0.632 \\
\hline \multicolumn{5}{|l|}{ 化学療法 } \\
\hline LIP 投与量 $(\mathrm{mL})$ & $8.5(3-10)$ & $9(1-14)$ & $10 \quad(6-19)$ & 0.058 \\
\hline CDDP 投与量 (mg) & $100(60-100)$ & $100(50-100)$ & $100(77-100)$ & 0.641 \\
\hline 術前輸液量 $(\mathrm{mL})$ & $1000(500-2000)$ & $1500 \quad(0-2500)$ & $2000 \quad(500-2500)$ & $0.012 *$ \\
\hline 術後輸液量 $(\mathrm{mL})$ & $2500(1500-4500)$ & $3000 \quad(1500-5500)$ & $3000(1000-4000)$ & 0.054 \\
\hline \multicolumn{5}{|l|}{ 術式 } \\
\hline TACE & $6(30 \%)$ & $10(27 \%)$ & $7(41 \%)$ & 0.576 \\
\hline TAI & $8(40 \%)$ & $19(51 \%)$ & $5(29 \%)$ & 0.301 \\
\hline $\mathrm{TACE} \cdot \mathrm{TAI}$ 併用 & $6(30 \%)$ & $8(22 \%)$ & $5(29 \%)$ & 0.727 \\
\hline
\end{tabular}

数值は中央值（最小值 - 最大值）および人数 $(\%)$ で表記. * $P<0.05$, a) chi-square test / Kruskal-Wallis test. AP: aprepitant, CDDP: cisplatin, DEX: dexamethasone, LIP: lipiodol, TACE: transcatheter arterial chemoembolization, TAI: transhepatic arterial infusion. 